forms of government which give to the working class in the community an effective voice in policy and administration."

"The temper, the outlook, the recreations, and the ideals of a nation may be so refined and raised by the right kind of training as to secure for the mass of the people a more choiceworthy life." J. WiLson.

\section{CHANGES IN COLOUR AMONG TROPICAL FISHES.}

THE Zoological Society of New York recently issued a very interesting paper written by $\mathrm{Mr}$. C. H. Townsend on the instantaneous changes of colour among tropical fishes (thirteenth annual report, 1909). The specimens came from the Bermudas, and are kept under favourable

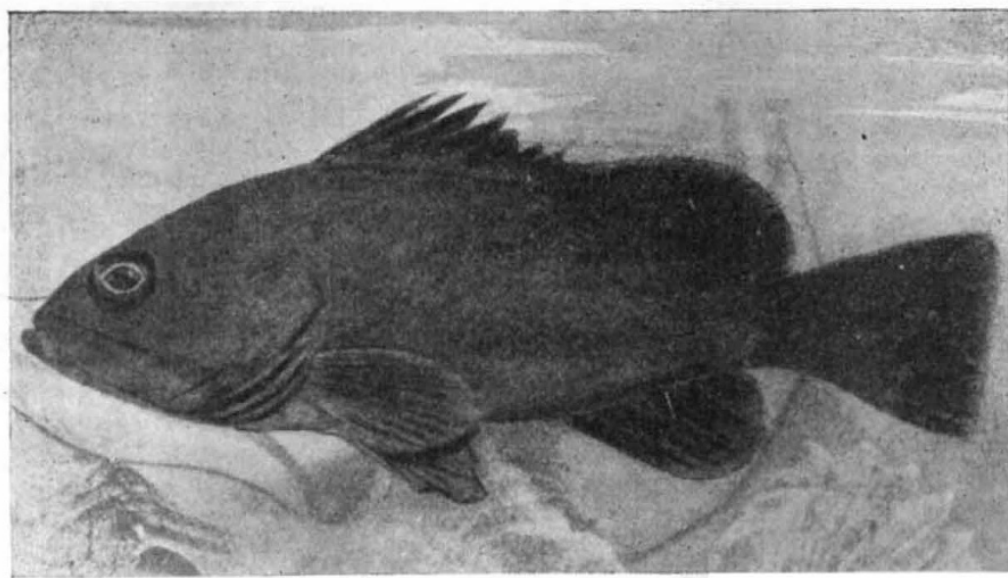

Dark Phase.

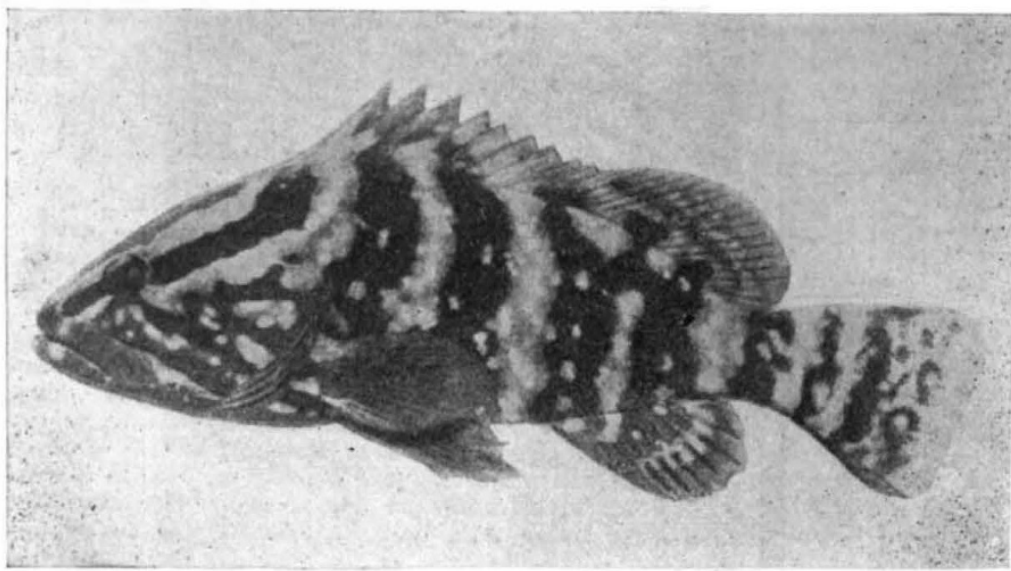

Banded Phase.

Two Colour-phases of the Nassau Grouper (Epinephelus striatus).

conditions in the aquarium of the society. The changes of coloration " begin to be in evidence within an hour of the arrival of new specimens, or as soon as they recover from the alarm produced by handling, and are produced as long as the fishes live in the tanks, which, in some cases, may be several years.'

The phases of coloration are illustrated by a striking series of photographs, two of which are reproduced. From these it will be seen that the fish can pass from a uniformly dark (plumbeous) colour to a banded phase with white markings. Four other phases can also be assumed, including a uniformly creamy-white one. This plasticity of coloration is characteristic of most of the fish dealt with, which include Serranidæ, Scaridæ, Teuthididæ, and Scorpænidæ. There is frequently a pale and a dark monochrome NO. 2075 , VOL. $\left.S_{I}\right]$ phase when the fish is at rest. Under any excitement, such as the presence of visitors, the fish assumes a parti-coloured aspect. This paper clearly shows how inadequate and misleading are many of the descriptions of colour hitherto accepted, and is a very suggestive and attractive piece of work. An error occurs on p. 3 , where it is said that "their different colours result from muscular action upon one or more kinds of cells." The mechanism of colour-change is not muscular, but nervous.

\section{MINERAL OUTPUT OF THE UNITED STATES.I}

THE well-known publication referred to below now appears in a form slightly different from the one to which we have hitherto been accustomed, being issued in two volumes, the first devoted to the Metallic products and the second to the Non-metallic products; this is done in consequence of a recent legislative enactment (Act of May 27, 1908), and presents some advantages, though it might be well to submit, with all respect, to the Government of the United States, that these (and sundry other) publications of the United States Geological Survey stand in far greater need of condensation than they do of expansion. When a work becomes unwieldy, there are two obvious remedies, either to issue it in two volumes or to compress the information it conveys into smaller compass; the latter is no doubt the more difficult proceeding, though the one that best serves the interests of the readers, and it is a matter of regret that, in this case, the line of least resistance has been followed. In the present instance it leads also to a few anomalies, as, for instance, the inclusion of crushed steel (as an abrasive) and of certain other metalliferous materials, such as arsenic, manganese, chromite, \&c., in the volume devoted to non-metallic products.

It is greatly to be regretted that the mineral statistics of the United States are issued in a form that makes comparisons with the mineral output of other nations difficult; for example, the various values of the metals are reported, not in the form of ore, but in the metallic state, though obviously the value in this form includes the cost of reduction of the metal, and leads to very serious duplication, which the compilers appear to have overlooked, although the introduction lays stress on the statement that " all unnecessary duplication has been excluded." To take an example, the production of iron ore is not given, but instead of it that of the pig-iron smelted from it, namely, nearly 26 million tons, valued at about 530 million dollars. Now the production of coke for the same year was 40 million tons, produced from 62 million tons of coal, valued at nearly 73 million dollars. Practically the whole of the pig-iron produced was made with coke as fuel, and, in the absence of exact figures, it will probably be a near approximation to the truth if we assume that three-fourths of the coke production, or, sar, 30 million tons, was consumed in the production of the above pig-iron, so that coal to the value of, say, 55 million dollars was utilised in this way, and this sum is accordingly included in the above valuation of the pig-iron production; it is, however, also included in the sum total of the value of the coal production, and thus enters twice

${ }_{1}$ Mineral Resources of the United S.atas, Calendar Year r 907. Part I., Metallic Products. Pp. 742. Part II.. Non-m-tallic Products. Pp. 897 . (Washington: Government Printing Office, 1908.) 